\begin{abstract}
The analysis is concerned with the contributions of numeracy and literacy to earnings, for three reasons: first, no clear pattern emerges from existing findings relating to the contributions of different types of ability, and numeracy and literacy appear to be a natural basic starting point; second, measures to improve numeracy and literacy are often given priority in policies intended to help those with lowest educational attainment; and third, with the growth of the knowledge-based economy, and the increasing importance of digital technology, it is of interest to compare the levels and rates of change of the contributions of numeracy and literacy as reflected in earnings. The results suggest that numeracy has a highly significant effect on earnings, mostly through its effect on college attainment, but also directly, controlling for attainment, and interactively with attainment, and its effect is subject to increasing returns. While the magnitude of the effect is small in absolute terms, it is substantial when compared with other effects, and it appears to be increasing at a rate of 6 percent per year. Literacy also has a highly significant effect on earnings, but it would appear to be indirectly through its effect on attainment. There is no evidence of a direct effect, an interactive effect with attainment, nonlinearity, or change through time.
\end{abstract}

This paper was produced as part of the Centre's

Labour Markets Programme 
Numeracy, Literacy, and Earnings:

Evidence from the National

Longitudinal Survey of Youth

\author{
Christopher Dougherty
}

November 2000 
Published by

Centre for Economic Performance

London School of Economics and Political Science

Houghton Street

London WC2A 2AE

8Christopher Dougherty, submitted September 2000

ISBN $075301422 \mathrm{X}$

Individual copy price: $£ 5$ 


\section{Numeracy, Literacy, and Earnings: Evidence from the National Longitudinal Survey of Youth}

\section{Christopher Dougherty}

Introduction

2. Previous Findings on the Impact of Numeracy and Literacy 1

3. Data 3

4. Results 5

5. Nonlinearities in the Impact of Numeracy and Literacy 6

6. Comparison with Previous Studies 6

$\begin{array}{ll}\text { Conclusions } & 7\end{array}$

$\begin{array}{lr}\text { Tables } & 8 \\ & \end{array}$

$\begin{array}{lr}\text { Appendices: } & 10\end{array}$

Figures $\quad 12$

Tables $\quad 15$

$\begin{array}{ll}\text { References } & 16\end{array}$ 


\section{Acknowledgements}

The author would like to thank Steven McIntosh, Anna Vignoles and participants in a CEP Tuesday Workshop for helpful comments.

Christopher Dougherty is a member of the Centre for Economic Performance and the Department of Economics, London School of Economics. 


\title{
Numeracy, Literacy, and Earnings: Evidence from the National Longitudinal Survey of Youth
}

\author{
Christopher Dougherty
}

\section{Introduction}

Concern with the increasing dispersion of earnings in the U.S. in the 1980s, and the actual decline in the earnings of the less qualified, has stimulated research into structural change in labour markets (Blackburn, Bloom and Freeman, 1990; Katz and Murphy, 1992; Levy and Murnane, 1992) and in particular has prompted a renewal of interest in the impact of education and ability on labour market outcomes. Previously, interest in ability had been largely subordinate to that in education, bias in the estimation of the return to education caused by the omission of ability or its inclusion with measurement error being a recurring motive for the investigation of its effects (Griliches and Mason, 1972; Hause, 1972; Chamberlain, 1977; Griliches, 1977). While such studies have employed a single, general measure of ability for this purpose, a few have investigated the effects of more specific measures, for instance contrasting the effects of academic skills with those of technical skills or the effect of numeracy with that of literacy.

The present analysis is concerned with the numeracy/literacy distinction, for three reasons. First, no clear pattern emerges from the existing findings relating to different types of ability. One reason for this is likely to be the heterogeneity in the definitions of the measures used. While numeracy and literacy themselves are susceptible to definitional flexibility, they appear to be a natural basic starting point for an investigation of the effects of different types of ability. Second, measures to improve numeracy and literacy are often given priority in policies intended to help those with lowest educational attainment. Third, with the growth of the knowledge-based economy, and the increasing importance of digital technology, it is of interest to compare the levels and rates of change of the contributions of numeracy and literacy as reflected in earnings.

\section{Previous Findings on the Impact of Numeracy and Literacy}

In one of the earliest studies in the earnings function literature, Hause (1972), using data from the 1966 Project Talent follow-up survey of white males originally interviewed in 1961, found that a quantitative ability composite, not further described, had a significant effect on the earnings of high school graduates and college graduates, but not on the earnings of high school or college drop-outs. The analysis does not include a counterpart measure of literacy.

Taubman and Wales (1974), using the 1969-1971 NBER-Thorndike-Hagen reinterview survey of male veterans who applied to join the Army Air Corps in 1943, found that a measure of mathematical ability had significant effects on the earnings of the respondents in 1955 and 1969. The measure was one of four ability factors constructed by Thorndike and Hagen through the application of factor analysis to the scores from a battery of 17 tests that included tests of coordination and knowledge as well as cognitive ability. The battery included a test of reading comprehension but the only ability factor with a substantial 
reading score weighting was dominated by scores from tests of knowledge of mechanical principles and knowledge relevant to air crew. Except in some specifications relating to 1969 earnings, where it had a significant adverse effect, this factor was not found to be a significant determinant of earnings.

Willis and Rosen (1979), also used the NBER-Thorndike-Hagen data set but selected their measures of ability from the scores on the individual tests, rather than the ThorndikeHagen ability factors, the score on a test of advanced arithmetic, algebra and trigonometry being their measure of mathematical ability and the score on the reading comprehension test being their verbal measure. They found that for those who attended at least some college, the mathematics and reading scores had positive effects on the earnings significant at the 0.1 percent and 1 percent level, respectively. For those high school graduates who did not attend college, the mathematics sore did not have a significant effect but the reading score did have an effect significant at the 0.1 percent level.

Bishop (1992), using data from the National Longitudinal Survey of Youth (NLSY), fitted earnings functions for males and females for each years from 1979 to 1986 separately. $\mathrm{He}$ found that a mathematics composite combining the score on a basic test of arithmetic reasoning and the score on a test of mathematics knowledge had an adverse effect on earnings in six of the eight years for males, neither of the positive coefficients being significant and two of the negative coefficients being significant at the 5 percent level. In the case of females, three of the coefficients were positive and significant at the 1 percent level, the other five being positive but insignificant. A verbal composite combining scores on word knowledge and paragraph comprehension tests had a negative impact on male earnings in all eight years, significantly negative at the 5 percent level in one year. For females, all but one of the coefficients were positive, but none was significant at the 5 percent level.

Blackburn and Neumark (1995), using NLSY data for males for 1985, were concerned with the impact of composite measures of academic and technical ability on earnings, rather than the effects of numeracy and literacy, but they do report that none of scores of tests of arithmetic reasoning, mathematics knowledge, word knowledge, or paragraph comprehension had a significant effect on earnings.

Murnane, Willett, and Levy (1995), using 1978 data from the National Longitudinal Study of the High School Class of 1972 and 1984 data from High School and Beyond to investigate the determinants of the increase in the premium for college education over high school education, found hat mathematical ability has a significant effect on earnings, controlling for educational attainment, and that an increase in the effect accounted for the apparent increase in the returns to college education between their sample dates. In addition they found that mathematical ability and years of schooling have an interactive effect on earnings for males, but not for females, in their 1978 data set, but they found the reverse for their 1984 data set. Scores on reading skills and vocabulary skills were available in both their data sets, but were found to have no significant effect on earnings and were dropped from the analysis.

McIntosh and Vignoles (2000), using the U.K. National Child Development Study and International Adult Literacy Survey data sets, found that numeracy has a significant effect on earnings, controlling for education. Using dummy variables for levels of numeracy, they were able to detect nonlinearity and found that its effect is strongest in the lowest part of its distribution. The impact of literacy on earnings was generally insignificant using the NCDS data, but they found some positive effects with the IALS data. 


\section{Data}

The data set used in the analysis, the NLSY, has three advantages over the main alternative, the National Longitudinal Survey of the High School Class of 1972: it has detailed labour force data, it is nationally representative and the data are more recent. The ability measures were added to the data set in 1980 as part of a project, known as Profile of American Youth, sponsored by the Department of Defense to update the crosswalks from raw to standardized scores in the Armed Services Vocational Aptitude Battery (ASVAB).

The ASVAB is a set of eight power tests, tests with a gradient in the difficulty of the items and generous time limits, and two speeded tests, tests with no gradient in difficulty and time limits so restrictive that few can complete them. All the tests are scaled so that they have mean 50 and standard deviation 10. The power tests comprise three basic tests of numeracy and literacy - tests of arithmetic reasoning, word knowledge, and paragraph comprehension - and five tests intended to predict success in training and performance in various military occupations - tests of mathematics knowledge, general science, automobile and workshop information, electronics knowledge, and mechanical comprehension.

Different studies have used the scores in different ways and with varying interpretations. Many, especially those concerned with controlling for the effects of ability in wage equations, have used a single measure, generally the Armed Forces Qualification Test (AFQT) composite used by the military to screen recruits. The AFQT was introduced in 1948 as the successor to tests that date back to World War I and there have been many changes in its underlying components and the method for combining them Bock and Moore, 1986). Initially, like its predecessor, it was based on verbal reasoning, numerical ability and spatial reasoning and thus might be interpreted as a proxy for IQ (Griliches and Mason, 1972). Since then it has shifted in the direction of measuring basic educational outcomes. The original AFQT score in the NLSY data set was based on arithmetic reasoning, word knowledge, paragraph comprehension, and numerical operations. The current version, dating from 1989, dropped the numerical operations component and included the mathematics knowledge score instead.

A critical issue in the use of the test scores is how, or indeed whether, they may be interpreted as measuring ability. At one end of the spectrum, Griliches and Mason (1972), citing previous studies, and with reservations, particularly with regard to measurement error, treat the AFQT as a military counterpart of a civilian IQ test. At the other end, some studies treat it as measuring learning (Hansen, Weisbrod, and Scanlon, 1970) or school quality (Maxwell, 1994).

With regard to the individual ASVAB tests, the tests of general science, mathematics knowledge, automobile and workshop information, electronics knowledge, and mechanical comprehension, and composites derived from them, are usually treated as specialized measures of educational attainment (Bock and Moore, 1986; Bishop, 1992; Blackburn and Neumark, 1993, 1995). However the status of arithmetic reasoning, word knowledge, and paragraph comprehension tests is less clear. The arithmetic knowledge score is sometimes combined with the mathematics knowledge score to form a mathematical composite that, by virtue of including mathematics knowledge, is a measure of attainment. By contrast, the word knowledge and paragraph comprehension tests are considered to be complementary and are combined as a verbal composite in the NLSY data set. Cook and Moore (1993) describe this as verbal aptitude, Bishop (1992) as verbal achievement. While the arithmetic reasoning, word knowledge, and paragraph comprehension tests are less education-intensive than the others, it is possible that scores on them could be improved by high school education, especially in the case of the least able, who may in high school still be studying elementary 
school material. This endogeneity could be expected to lead to inconsistent estimates of their effects if used as regressors in an educational attainment model.

Further, the potential endogeneity calls into question the practice of adjusting the scores for age. The tests are intended to be taken by high school graduates at about the age of 18, but the NLSY respondents were aged 15 to 23 at the time of the Profiles project. Some studies (for example, Blackburn and Neumark, 1993, 1995; Arkes, 1999) have sought to compensate for the variations in age by regressing the test scores on individual age dummies and replacing the scores by the residuals from these regressions. However, variations in schooling at the time of taking the test are at least as likely to be responsible for the variations in the scores, and age may merely be acting as a proxy. This could account for the implausibly large increments in the age dummy coefficients after the age of 18, by which age further improvement should be minimal (Appendix Table A.1). It could also account for the fact that age has a significantly negative coefficient when the scores are regressed on schooling at the time of taking the tests and age together, the endogeneity of schooling causing its coefficient to be biased upwards and thus that of age downwards (Appendix Table A.2).

In the case of earnings functions, the effects of variations in the definitions of composites are more subtle. If years of schooling are being used as a proxy for a measure of education that included school quality, and if scores on the knowledge-based tests can be taken as partial measures of educational outputs that reflect variations in educational quality, inclusion of such scores may cause estimates of the returns to education to be downwards biased.

Since the present paper is concerned with the impact of basic numeracy and literacy on outcomes, arithmetic reasoning, and word knowledge and paragraph comprehension, in the form of the verbal composite, are the only power tests used in the analysis. Example test items are presented in Appendix B.

Scores on the two speeded tests, numerical operations and coding speed, are clearly dependent on personal qualities not usually associated with education. In both cases the test items are so simple that virtually every respondent could answer every item correctly, given enough time (NLSY Users Guide, 1992). Accordingly, the numerical operations score might be regarded as a simple measure of the speed at which a subject is able and willing to perform mental operations, combined with motivation. The coding speed test is similar in status but evaluates short-term memory. Bock and Moore (1986) describe both tests as fatiguing and boring and as rewarding concentration and persistence.

Any analysis of the determinants of earnings is potentially susceptible to biases arising from the endogeneity of schooling. The strategy that has been adopted here is to condition the analysis as fully as possible on family background and other control factors, including the scores on the numerical operations and coding speeded tests, parental education, ethnicity, whether living in a town, non-farm rural area, farm, or abroad at ge 14, tenure, work experience, region of current residence, whether living in an SMSA (with subcategories), local area unemployment rate, and unionization. Card (1999) shows that using family background variables to instrument for education in a wage equation when a measure of ability is lacking is likely to lead to an upwards bias greater than that in an OLS regression, and that including the family background variables in the model, rather than instrumenting with them, leads to a smaller bias than either. Although ability variables are included in the present model, they are undoubtedly imperfect and for that reason the family background variables have been retained. In principle the inclusion of irrelevant variables in an earnings function can aggravate a downwards bias in the estimate of the education effect if there is measurement error in the education variable (Griliches, 1977), but in the NLSY data set 
education is measured relatively accurately and so this would not appear to be a potential problem.

\section{Results}

The first column of Table 1 presents the results of regressing the logarithm of hourly earnings on numeracy, literacy, tenure, years of work experience, time, and interactive terms for numeracy and literacy with time and years of work experience. In this reduced form specification, the coefficients of numeracy, literacy, and the interactive terms should be interpreted as estimates of the total effects, both direct and indirect through an impact on the excluded schooling variables. The regression suggests that the overall effect of numeracy on earnings is much larger than that of literacy. The coefficients indicate that a one-standarddeviation gain (10 points) is associated with a 9.5 percent increase in earnings in the case of numeracy but only 1.4 percent in the case of literacy; the coefficient of numeracy is significant at the 0.1 percent level but that of literacy is not significant in this specification. Further, the coefficient of the numeracy-time interactive variable, significant at the 1 percent level, suggests that the impact of numeracy on earnings grew at a rate of 6 percent per year. There was no interaction between literacy and time, and no significant interaction between either numeracy or literacy and years of work experience.

The fourth column of Table 1 presents the results of adding years of high school and years of college, and interactive terms with numeracy and literacy, to the specification. The schooling coefficients indicate that the impact of college on earnings is much greater than that of high school, the increment per year of college being 5.7 percent and significant at the 0.1 percent level, but that per year of high school being only 1.2 percent, not significant, and subject to a significant downward trend. In addition to any effect it might have via an influence on educational attainment, numeracy has effects significant at the 0.1 percent level both directly and via an interactive effect with years of college. Literacy has a smaller, but significant, direct effect but no significant interactive effect.

The increasing impact of numeracy on earnings found in the reduced form regression could be due to an increase in its own direct effect, controlling for schooling, an increase in its interactive effect with schooling, or an indirect effect through its impact on educational attainment and a change in the impact of attainment on earnings. The first possibility is in principle difficult to detect. The estimate of the direct effect of numeracy, while significant at the 5 percent level, is small. It follows that estimates of annual change, which are bound to be much smaller still, are unlikely to be statistically significant, as in this case. For what it is worth, the estimate is positive and accounts for a hird of the numeracy-time coefficient in the reduced form regression. The second possibility, that the increased impact of numeracy on earnings has been through an increase in the interactive impact of numeracy on the returns to years of college, was investigated with a triple interactive term. Its coefficient was zero to four decimal places and the regression results, not shown, were otherwise very close to those in the fourth column of Table 1.

The third possibility is that the value of numeracy has increased indirectly as a consequence of its impact on educational attainment and increasing economic returns to attainment. This first part of this hypothesis is supported by the tobit regression reported in Table 2, which indicates that numeracy has a highly significant effect on years of college completed. The second part of the hypothesis is supported by the positive coefficient of the interactive term for college and time in the third column of Table 1. It is significant only at the 5 percent level, but the small size of the trend made a higher degree of significance improbable. 
Table 2 indicates that literacy also has a highly significant effect on college attainment. However the reduced form regression in the second column of Table 1 indicates that the economic value of literacy has not increased with time, despite the increased value of college attainment. The result suggests that while literacy has an impact on college attainment, it is primarily on attainment that has not been increasingly rewarded in the market place. As a matter of speculation, the asymmetry between the impact of numeracy and literacy might be explained on the lines of numeracy leading to success in technical degrees that are increasing in relative value, while literacy favours success in liberal-arts degrees.

Tables 1 and 2 also present regressions disaggregated by sex, with similar findings, the only important difference being a higher return to years of college for females, significant at the 0.1 percent level.

\section{Nonlinearities in the Impact of Numeracy and Literacy}

Thus far it has been assumed that, apart from potential interactive effects, the impact of numeracy and literacy on earnings is linear. If their effect is nonlinear and concave, a marginal improvement could be disproportionately beneficial to those with lowest ability and would strengthen the arguments for devoting second-chance resources to them. Unfortunately, in the case of numeracy, there is a strongly nonlinear impact on attainment, and hence on earnings, but it is convex. Table 3 presents the results of adding quadratic terms in numeracy and literacy. The coefficient of the quadratic term, defined for both numeracy and literacy as the squared deviation from the mean of 50, implies that the impact of marginal changes in numeracy on earnings for an individual two standard deviations (20) below the mean is only 0.0022 , and that a gain of one standard deviation on the score would raise earnings by only about 3.5 percent. The results for literacy, where there is no significant nonlinearity, are mixed. A 10 point gain translates to more than an extra year of educational attainment, but the impact on earnings is no greater than that for numeracy.

\section{Comparison with Previous Studies}

Direct comparison of these findings with those of previous studies is complicated by differences in definitions and measures (see Appendix B), but they would seem to be consistent with those of Taubman and Wales (1974), Willis and Rosen (1979), Murnane, Willett, and Levy (1995) and McIntosh and Vignoles (2000), all of whom found that numeracy in various forms has a positive impact on earnings, controlling for educational attainment. The present findings are particularly close to those of Taubman and Wales, and Willis and Rosen, in that there appears to be strongly increasing returns to numeracy on earnings, and they differ from those of McIntosh and Vignoles in that respect. The findings conflict with those of Bishop (1992) and Blackburn and Neumark (1995), but it is possible that the reason that these studies did not find an effect is that they used early rounds from the NLSY when the more able respondents were either still in school or relatively new in the labour market.

Murnane, Willett, and Levy also found interactive effects between years of schooling and numeracy, for males, but not females, in their 1978 data set, and for females, but not males, in their 1984 data set.

The finding that literacy has only a weakly significant effect on earnings, controlling for educational attainment, is also generally consistent with those of previous studies, all but one of which found no significant effect at all. The exception is Willis and Rosen (1979), 
who found that it had a smaller effect than numeracy for their higher-ability group and a greater one for their lower-ability group, as in the present case.

\section{Conclusions}

The foregoing results suggest that numeracy has a highly significant effect on earnings, mostly through its effect on college attainment, but also directly, controlling for attainment, and interactively with attainment. Further, there appears to be increasing returns to the impact of numeracy on earnings, again through increasing returns to its effect on attainment.

The magnitude of the effect is small in absolute terms, an increase of one standard deviation in the middle of the distribution being associated with a 10 percent increase in earnings, but it is substantial when compared with other effects. For example, it is equivalent to about two years of college, and moreover it appears to be increasing, probably as a consequence of a rise in the economic value of years of college, the estimated growth rate during the 1988-1996 period covered being 6 percent per year.

Literacy also has a highly significant effect on earnings, but it would appear to be mostly indirectly through its effect on attainment. There is no evidence of a direct effect, an interactive effect with attainment, nonlinearity, or change through time. Because of the absence of nonlinearity, measures to improve literacy may have more impact than measures to improve numeracy on the earnings of the least able, but the difference is not great and the quantitative effects appear to be small. 
Table 1: Dependent Variable Logarithm of Hourly Earnings

\begin{tabular}{|c|c|c|c|c|c|c|}
\hline & $\begin{array}{l}\text { (1) } \\
\text { All }\end{array}$ & $\begin{array}{c}\text { (2) } \\
\text { Males }\end{array}$ & $\begin{array}{c}\text { (3) } \\
\text { Females }\end{array}$ & $\begin{array}{l}\text { (4) } \\
\text { All }\end{array}$ & $\begin{array}{c}\text { (5) } \\
\text { Males }\end{array}$ & $\begin{array}{c}(6) \\
\text { Females }\end{array}$ \\
\hline Time & $\begin{array}{l}-0.0007 \\
(0.0018)\end{array}$ & $\begin{array}{c}0.0025 \\
(0.0027)\end{array}$ & $\begin{array}{l}-0.0043 \\
(0.0026)\end{array}$ & - & - & - \\
\hline High school & - & - & - & $\begin{array}{c}0.0124 \\
(0.0096)\end{array}$ & $\begin{array}{c}0.0053 \\
(0.0129)\end{array}$ & $\begin{array}{c}0.0182 \\
(0.0147)\end{array}$ \\
\hline $\begin{array}{l}\text { High school* } \\
\text { Time }\end{array}$ & - & - & - & $\begin{array}{l}-0.0007 * * * \\
(0.0002)\end{array}$ & $\begin{array}{l}-0.0006^{*} \\
(0.0003)\end{array}$ & $\begin{array}{l}-0.0009 * * * \\
(0.0002)\end{array}$ \\
\hline College & - & - & - & $\begin{array}{l}0.0571 * * * \\
(0.0030)\end{array}$ & $\begin{array}{l}0.0499 * * * \\
(0.0046)\end{array}$ & $\begin{array}{l}0.0654 * * * \\
(0.0039)\end{array}$ \\
\hline College*Time & - & - & - & $\begin{array}{l}0.0016^{*} \\
(0.0007)\end{array}$ & $\begin{array}{c}0.0023^{*} \\
(0.0010)\end{array}$ & $\begin{array}{c}0.0013 \\
(0.0010)\end{array}$ \\
\hline Numeracy & $\begin{array}{l}0.0095 * * * \\
(0.0019)\end{array}$ & $\begin{array}{l}0.0077 * * \\
(0.0030)\end{array}$ & $\begin{array}{l}0.0084 * * * \\
(0.0026)\end{array}$ & $\begin{array}{l}0.0028^{* * * *} \\
(0.0008)\end{array}$ & $\begin{array}{c}0.0017 \\
(0.0012)\end{array}$ & $\begin{array}{c}0.0017 \\
(0.0012)\end{array}$ \\
\hline $\begin{array}{l}\text { High school* } \\
\text { Numeracy }\end{array}$ & - & - & - & $\begin{array}{l}-0.0005 \\
(0.0009)\end{array}$ & $\begin{array}{c}0.0003 \\
(0.0012)\end{array}$ & $\begin{array}{l}-0.0022 \\
(0.0015)\end{array}$ \\
\hline $\begin{array}{l}\text { College* } \\
\text { Numeracy }\end{array}$ & - & - & - & $\begin{array}{l}0.0011^{* * * *} \\
(0.0003)\end{array}$ & $\begin{array}{l}0.0013^{* *} \\
(0.0005)\end{array}$ & $\begin{array}{l}0.0019 * * * \\
(0.0004)\end{array}$ \\
\hline Numeracy*Time & $\begin{array}{l}0.0006^{* *} \\
(0.0002)\end{array}$ & $\begin{array}{c}0.0008^{*} \\
(0.0004)\end{array}$ & $\begin{array}{c}0.0000 \\
(0.0003)\end{array}$ & $\begin{array}{c}0.0002 \\
(0.0002)\end{array}$ & $\begin{array}{c}0.0003 \\
(0.0003)\end{array}$ & $\begin{array}{l}-0.0001 \\
(0.0003)\end{array}$ \\
\hline Literacy & $\begin{array}{c}0.0014 \\
(0.0018)\end{array}$ & $\begin{array}{c}0.0025 \\
(0.0028)\end{array}$ & $\begin{array}{c}0.0027 \\
(0.0023)\end{array}$ & $\begin{array}{c}0.0019 * \\
(0.0008)\end{array}$ & $\begin{array}{c}0.0020^{*} \\
(0.0011)\end{array}$ & $\begin{array}{l}0.0028^{* *} \\
(0.0012)\end{array}$ \\
\hline $\begin{array}{l}\text { High school* } \\
\text { Literacy }\end{array}$ & - & - & - & $\begin{array}{c}0.0007 \\
(0.0007)\end{array}$ & $\begin{array}{c}0.0000 \\
(0.0009)\end{array}$ & $\begin{array}{r}0.0019 * \\
(0.0011)\end{array}$ \\
\hline College*Literacy & - & - & - & $\begin{array}{l}-0.0006 \\
(0.0004)\end{array}$ & $\begin{array}{l}-0.0008 \\
(0.0006)\end{array}$ & $\begin{array}{l}-0.0010 \\
(0.0006)\end{array}$ \\
\hline Literacy*Time & $\begin{array}{c}0.0000 \\
(0.0002)\end{array}$ & $\begin{array}{c}0.0001 \\
(0.0004)\end{array}$ & $\begin{array}{c}0.0002 \\
(0.0003)\end{array}$ & $\begin{array}{c}0.0000 \\
(0.0002)\end{array}$ & $\begin{array}{c}0.0000 \\
(0.0003)\end{array}$ & $\begin{array}{c}0.0001 \\
(0.0003)\end{array}$ \\
\hline Tenure & $\begin{array}{l}0.0468 * * * \\
(0.0030)\end{array}$ & $\begin{array}{l}0.0407 * * * \\
(0.0040)\end{array}$ & $\begin{array}{l}0.0544 * * * \\
(0.0043)\end{array}$ & $\begin{array}{l}0.0451 * * * \\
(0.0029)\end{array}$ & $\begin{array}{l}0.0386^{* * * *} \\
(0.0040)\end{array}$ & $\begin{array}{l}0.0537 * * * \\
(0.0042)\end{array}$ \\
\hline Tenure squared & $\begin{array}{l}-0.0023 * * * \\
(0.0002)\end{array}$ & $\begin{array}{l}0.0020 * * * \\
(0.0003)\end{array}$ & $\begin{array}{l}0.0027 * * * \\
(0.0003)\end{array}$ & $\begin{array}{l}-0.0020 * * * \\
(0.0002)\end{array}$ & $\begin{array}{l}-0.0017 * * * \\
(0.0003)\end{array}$ & $\begin{array}{l}-0.0025 * * * \\
(0.0003)\end{array}$ \\
\hline $\begin{array}{l}\text { Years of work } \\
\text { experience }\end{array}$ & $\begin{array}{l}0.0289 * * * \\
(0.0046)\end{array}$ & $\begin{array}{l}0.0214 * * \\
(0.0069)\end{array}$ & $\begin{array}{l}0.0298 * * * \\
(0.0063)\end{array}$ & $\begin{array}{l}0.0313 * * * \\
(0.0044)\end{array}$ & $\begin{array}{l}0.0260 * * * \\
(0.0068)\end{array}$ & $\begin{array}{l}0.0285^{* * * *} \\
(0.0058)\end{array}$ \\
\hline Years squared & $\begin{array}{l}-0.0004^{*} \\
(0.0002)\end{array}$ & $\begin{array}{l}-0.0002 \\
(0.0003)\end{array}$ & $\begin{array}{l}-0.0004 \\
(0.0003)\end{array}$ & $\begin{array}{l}-0.0004^{*} \\
(0.0002)\end{array}$ & $\begin{array}{l}-0.0003 \\
(0.0003)\end{array}$ & $\begin{array}{l}-0.0002 \\
(0.0003)\end{array}$ \\
\hline Numeracy*Years & $\begin{array}{l}-0.0002 \\
(0.0002)\end{array}$ & $\begin{array}{l}-0.0002 \\
(0.0003)\end{array}$ & $\begin{array}{c}0.0001 \\
(0.0003)\end{array}$ & - & - & - \\
\hline Literacy*Years & $\begin{array}{c}0.0001 \\
(0.0002)\end{array}$ & $\begin{array}{c}0.0000 \\
(0.0003)\end{array}$ & $\begin{array}{c}0.0000 \\
(0.0003)\end{array}$ & - & - & - \\
\hline$R^{2}$ & 0.387 & 0.353 & 0.399 & 0.421 & 0.382 & 0.448 \\
\hline$n$ & 10,157 & 5,660 & 4,497 & 10,157 & 5,660 & 4,497 \\
\hline
\end{tabular}

Note: *,**, *** significant at the 5 percent, 1 percent, and 0.1 percent levels. Controls include the scores on the ASVAB numerical operations and coding speeded tests, parental education, ethnicity, whether living in a town, non-farm rural area, farm, or abroad at age 14, region of current residence, whether living in an SMSA (with subcategories), local area unemployment rate, and unionization. 
Table 2: Years of College Completed, Tobit Regression

\begin{tabular}{lccc}
\hline & $(1)$ & $(2)$ & $(3)$ \\
& All & Males & Females \\
\hline \multirow{2}{*}{ Numeracy } & $0.0896^{* * *}$ & $0.0870^{* * *}$ & $0.0890^{* * *}$ \\
& $(0.0074)$ & $(0.0116)$ & $(0.0096)$ \\
Literacy & $0.1157^{* * *}$ & $0.1245^{* * *}$ & $0.1090^{* * *}$ \\
& $(0.0088)$ & $(0.0134)$ & $(0.0118)$ \\
$n$ & 4,959 & 2,386 & 2,573 \\
\hline
\end{tabular}

Note: $* * *$ significant at the 0.1 percent level. Controls include the scores on the ASVAB numerical operations and coding speeded tests, parental education, ethnicity, whether living in a town, non-farm rural area, farm, or abroad at age 14.

Table 3: Earnings and Educational Attainment

\begin{tabular}{lcc}
\hline & $\begin{array}{c}\text { Years of College } \\
\text { Completed }\end{array}$ & $\begin{array}{c}\text { Logarithm of } \\
\text { Hourly Earnings }\end{array}$ \\
\hline Time & - & -0.00194 \\
Numeracy & $0.0756^{* * *}$ & $(0.00179)$ \\
& $(0.0078)$ & $0.00724^{* * *}$ \\
Numeracy squared & $0.0030^{* * *}$ & $(0.00069)$ \\
& $(0.0006)$ & $0.00025^{* * *}$ \\
Literacy & $0.1290^{* * * *}$ & $(0.00005)$ \\
Literacy squared & $(0.0099)$ & $0.00358^{* * *}$ \\
& 0.0007 & $(0.00087)$ \\
$R^{2}$ & $(0.0006)$ & 0.00005 \\
$n$ & & $(0.00005)$ \\
& 4,959 & 0.388 \\
\hline
\end{tabular}

Note: As for Tables 1 and 2. 


\section{Appendix A. Age-Adjusted ASVAB Scores}

The Armed Services Vocational Aptitude Battery was administered to $94.4 \%$ of the NLSY core respondents in 1980 as part of the Profiles of American Youth project to re-norm the scaling of the ASVAB scores and the Armed Forces Qualification Test. The battery is intended to be taken by young people considering enlisting in the Armed Services at around the time that they graduate from high school but, at the time of the Profiles project, the NLSY respondents were aged 15 to 23 and thus some were considerably under-age and others overage. To compensate for this, some analysts have adjusted the scores by regressing them on age dummy variables and replacing them with the residuals from the regressions. The regressions for arithmetic reasoning, word knowledge, and paragraph comprehension are shown in Table B.1 (omitted category: age 18).

However, whether this is an appropriate procedure must be open to some doubt, for education is at least as age to be responsible for the variations in the scores, and when the scores are regressed on both, age has a negative coefficient, significant at the 0.1 percent level, in each case. The likely reason for this is that educational attainment is positively influenced by the scores, and hence the schooling variable in the regression is endogenous. As a consequence, the estimates of its coefficient in Table B.2 are biased upwards, causing that of the age variable to be biased downwards. It is thus not clear that the residuals from the age-adjustment regressions are preferable to the unadjusted scores, and no such adjustment has been made in the present analysis. It should be noted that in any case the age dummy variables are associated with a very small proportion of the variance in the ASVAB scores - 3.5 percent in the case of word knowledge and about half that for arithmetic reasoning and paragraph comprehension.

\section{Appendix B. Measures of Numeracy and Literacy}

The measure of numeracy used in the analysis is the score on the ASVAB test of arithmetic reasoning. According to Bock and Moore (1986), the standard monograph on the project, the arithmetic reasoning test involves addition, subtraction, multiplication, and division of integers and fractions, but not mental arithmetic. The measure of literacy used in the analysis is the verbal composite in the NLSY data set that combines the scores on the ASVAB tests of word knowledge, described by Bock and Moore as a straightforward vocabulary test, and paragraph comprehension, described as a test of reading comprehension rather than literal reading ability. Example items provided by Bock and Moore are shown in Figure B.1. The scale in the figure has mean 500 and standard deviation 100, and the location of the items indicates the score of an individual with 50 percent probability of answering the item correctly.

Of previous studies that have investigated the effects of quantitative and verbal ability, Bishop (1992) and Blackburn and Neumark (1995) also used the ASVAB scores. However, Bishop's quantitative measure, described as mathematical achievement, is a composite of the arithmetic reasoning score and the score on the test of mathematics knowledge, considered by Bock and Moore to be the most educationally demanding of the ten tests and requiring exposure to high school algebra and geometry. His measure of verbal ability, described as verbal achievement, is the same verbal composite, normalized in common with his other measures of ability so as to have zero mean and unit variance. Blackburn and Neumark (1995) were concerned primarily with effects of academic and technical composites, rather than numeracy and literacy, but in an appendix they disclose the 
results obtained using all ten ASVAB test scores individually in one of the specifications of their earnings functions.

The tests of numeracy and literacy administered to the high school seniors in the two cohorts studied by Murnane, Willett, and Levy (1995) are similar technically to those in the ASVAB, being scaled using a three-parameter item response curve and, judging by the examples presented, they also appear similar in content. Murnane, Willett, and Levy state that the mathematics test covers elementary mathematical concepts taught in American schools no later than eighth grade and assesses students' skill in following directions, working with fractions and decimals, and interpreting line graphs. They refer to the test score as a measure of cognitive ability.

The mathematical ability factor used by Taubman and Wales (1974) contained substantial weightings from a variety of mathematics-related subtests, ranging from a test of numerical operations similar to the ASVAB test thus described to a mathematics test involving advanced arithmetic, algebra, and trigonometry. Willis and Rosen (1979) used the latter as their measure of quantitative ability and the score on the reading comprehension subtest, said by them to be at a college undergraduate level, as their measure of verbal ability.

The numeracy and literacy tests used by McIntosh and Vignoles (2000) were devised by the U.K. Basic Skills Agency and are described as measuring the ability to use these skills in an everyday context. The Basic Skills Agency is primarily concerned with those at the low-skill end of the spectrum and the tests are no more demanding than the corresponding ASVAB tests.

Thus most of the studies have used measures of numeracy and literacy skills that ought to have been acquired before the completion of high school. The exceptions are Willis and Rosen (1979), where the measures appear to be of college-level skills, and Taubman and Wales (1974), where the mathematical measure is based on subtests with heterogeneous skill levels. 


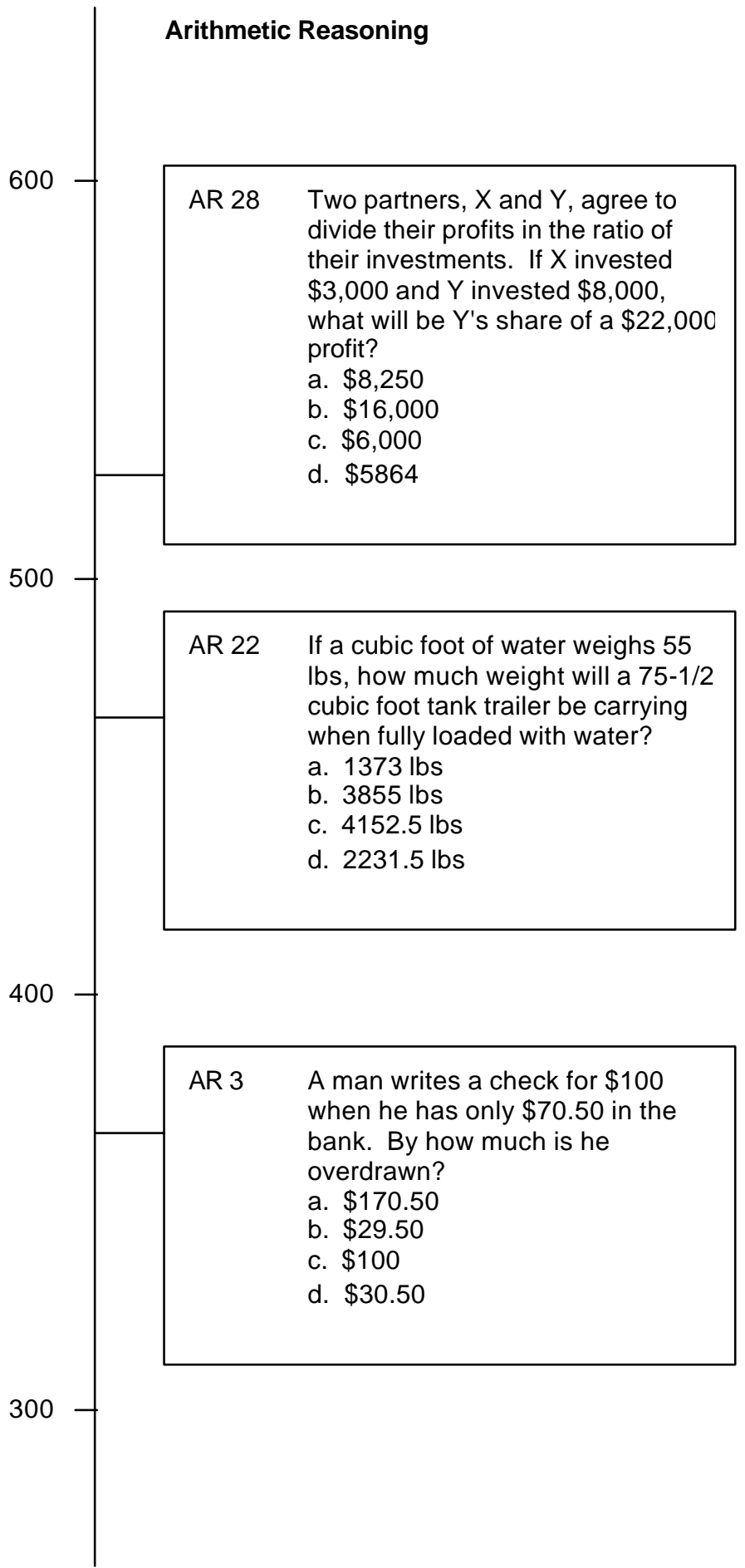

Figure B.1a 


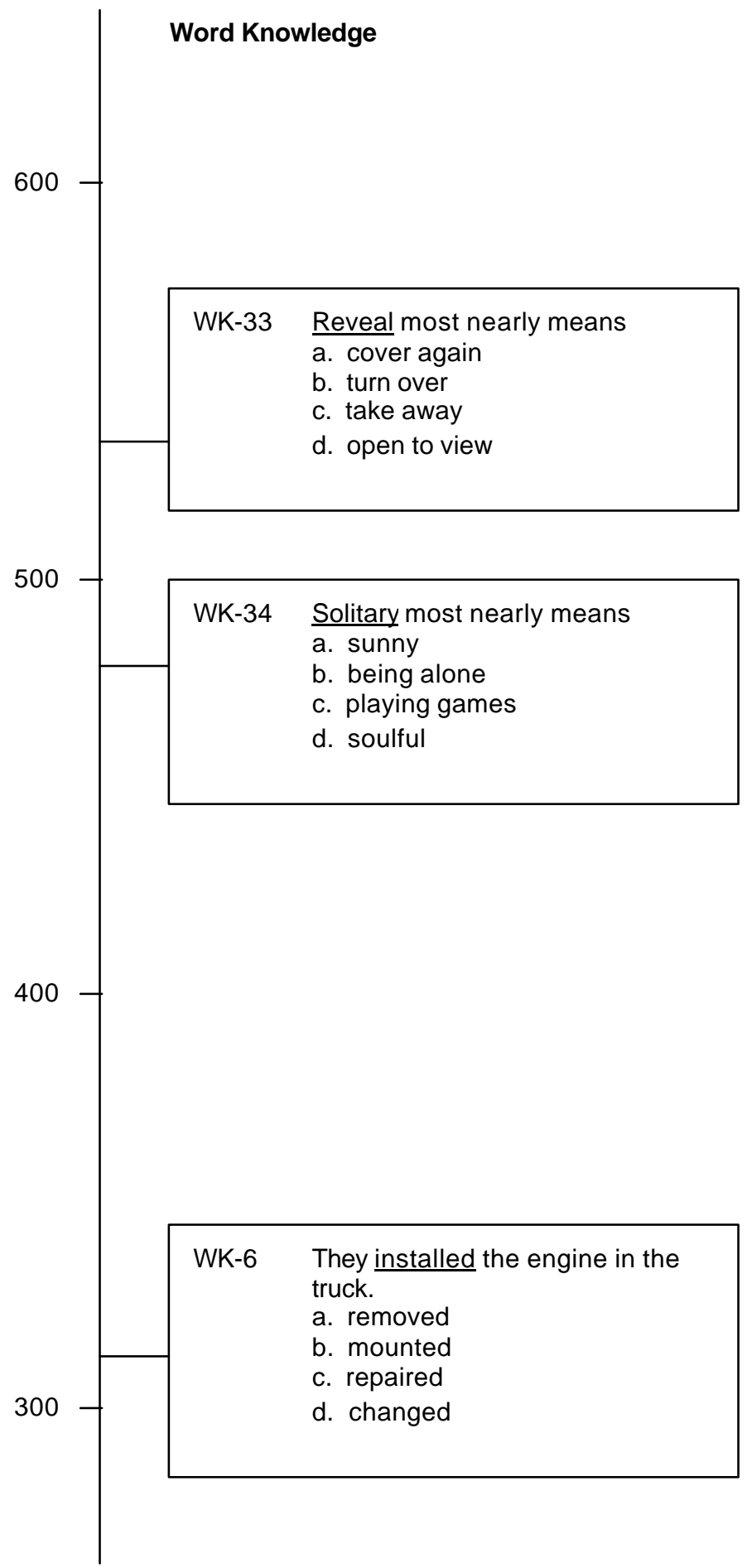

Figure B.1b 


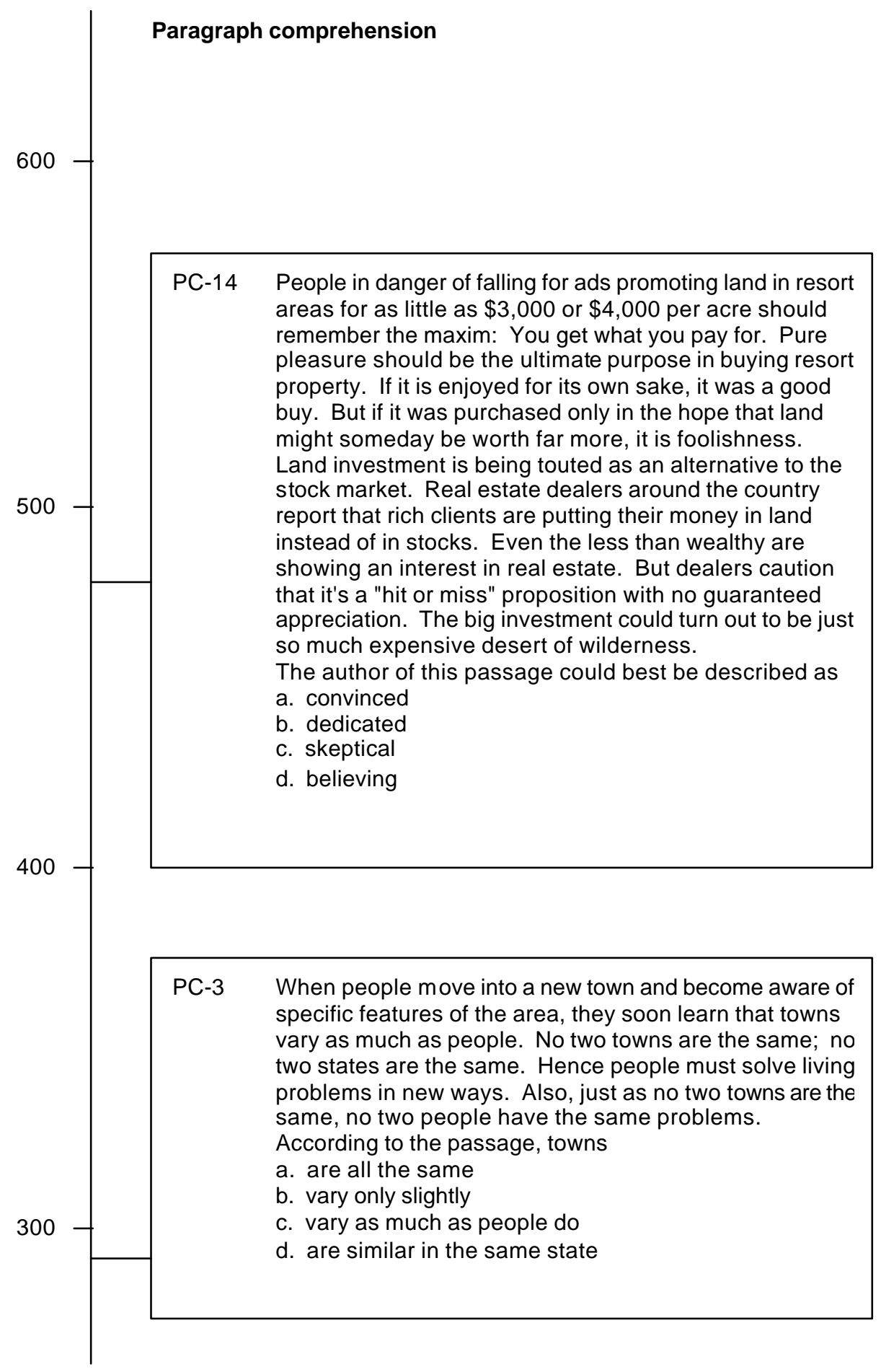

Figure B.1c 
Table A.1 ASVAB Scores Regressed on Age at Time of

Taking the Tests

\begin{tabular}{cccc}
\hline $\begin{array}{c}\text { Age at } \\
\text { time of test }\end{array}$ & $\begin{array}{c}\text { Arithmetic } \\
\text { reasoning }\end{array}$ & $\begin{array}{c}\text { Word } \\
\text { knowledge }\end{array}$ & $\begin{array}{c}\text { Paragraph } \\
\text { comprehension }\end{array}$ \\
\hline 14 & -2.07 & -3.78 & -3.51 \\
& $(0.56)$ & $(0.57)$ & $(0.58)$ \\
15 & -1.17 & -2.35 & -1.93 \\
& $(0.50)$ & $(0.50)$ & $(0.52)$ \\
16 & -0.37 & -1.54 & -1.16 \\
& $(0.49)$ & $(0.50)$ & $(0.52)$ \\
17 & -0.13 & -0.48 & -0.27 \\
& $(0.50)$ & $(0.50)$ & $(0.52)$ \\
19 & 0.86 & 0.54 & 0.31 \\
& $(0.51)$ & $(0.52)$ & $(0.54)$ \\
20 & 1.83 & 2.12 & 1.37 \\
& $(0.53)$ & $(0.54)$ & $(0.56)$ \\
21 & 2.06 & 2.35 & 1.70 \\
& $(0.53)$ & $(0.54)$ & $(0.56)$ \\
22 & 2.64 & 2.94 & 2.02 \\
& $(0.92)$ & $(0.93)$ & $(0.96)$ \\
$R^{2}$ & 0.017 & 0.035 & 0.021 \\
$n$ & 5,751 & 5,751 & 5.751 \\
\hline
\end{tabular}

Table A.2 ASVAB Scores Regressed on Schooling and Age at Time of Test

\begin{tabular}{lccc}
\hline & $\begin{array}{c}\text { Arithmetic } \\
\text { reasoning }\end{array}$ & $\begin{array}{c}\text { Word } \\
\text { knowledge }\end{array}$ & $\begin{array}{c}\text { Paragraph } \\
\text { comprehension }\end{array}$ \\
\hline $\boldsymbol{H G C 8 0}$ & $3.110 * * *$ & $3.299 * * *$ & $3.260 * * *$ \\
& $(0.077)$ & $(0.076)$ & $(0.080)$ \\
Age & $-0.792 * * *$ & $-0.602 * * *$ & $-0.760 * * *$ \\
& $(0.061)$ & $(0.061)$ & $(0.064)$ \\
$R^{2}$ & 0.239 & 0.275 & 0.244 \\
$n$ & 5,676 & 5,676 & 5,676 \\
\hline
\end{tabular}

Note: $* * *$ significant at the 0.1 percent level. 


\section{References}

Arkes, J. (1999), 'What Do Educational Credentials Signal and Why Do Employers Value Credentials?', Economics of Education Review, 18 (1), pp.133-141.

Bishop, J. H. (1992), 'The Impact of Academic Competencies on Wages, Unemployment, and Job Performance', Carnegie-Rochester Conference Series on Public Policy 37, pp.127194.

Blackburn, M. L., Bloom, D. E. and Freeman, R. B. (1990), 'The Declining Economic Position of Less Skilled American Men', in G. Burtless (ed), A Future of Lousy Jobs?, Washington DC: Brookings Institution.

Blackburn, M. L. and Neumark, D. (1993), 'Omitted-Ability Bias and the Increase in the Return to Schooling', Journal of Labor Economics, 11 (3), pp.521-544.

Blackburn, M. L. and Neumark, D. (1995), 'Are OLS Estimates of the Return to Schooling Biased Downward? Another Look', Review of Economics and Statistics, 77 (2), pp.217-230.

Bock, R. D. and Moore, E. G. J. (1986), Advantage and Disadvantage: A Profile of American Youth, Lawrence Erlbaum Associates: Hillsdale, New Jersey.

Card, D. (1999), 'The Causal Effect of Education on Earnings', in O.C. Ashenfelter and D. Card (eds), Handbook of Labor Economics Volume 3A, Elsevier: New York.

Chamberlain, G. (1977), 'Education, Income, and Ability Revisited', Journal of Econometrics, 5 (2), pp.241-257.

Cook, P. J. and Moore, M. J. (1993), 'Drinking and Schooling', Journal of Health Economics, 12 (4), pp.411-429.

Griliches, Z. (1977), 'Estimating the Returns of Schooling: Some Econometric Problems', Econometrica, 45 (1), pp.1-22.

Griliches, Z. and Mason, W. M. (1972), 'Education, Income and Ability', Journal of Political Economy, 80 (3 pt 2), S74-S103.

Hansen, W. L., Weisbrod, B. A. and Scanlon, W. J. (1970), 'Schooling and Earnings of Low Achievers', American Economic Review, 60 (3), pp.409-418.

Hause, J. C. (1972), 'Earnings Profile: Ability and Schooling', Journal of Political Economy, 80 (3 pt 2), S108-S138.

Katz, L. F. and Murphy, K. M. (1992), 'Changes in Relative Wages 1963-1987: Supply and Demand Factors', Quarterly Journal of Economics, 107 (1), pp.35-78. 
Levy, F., and Murnane, R. J. (1992), 'U.S. Earnings Levels and Earnings Inequality: A Review of Recent Trends and Proposed Explanations', Journal of Economic Literature, 30 (3), pp.1333-1381.

Maxwell, N. L. (1994), 'The Effect on Black-White Wage Differences of Differences in the Quantity and Quality of Education', Industrial and Labor Relations Review, 47 (2), pp.249-264.

McIntosh, S., and Vignoles, A. (2000), 'Measuring and Assessing the Impact of Basic Skills on Labour Market Outcomes', Discussion Paper No.6, Centre for the Economics of Education, London School of Economics.

Murnane, R. J., Willett, J. B. and Levy, F. (1995), 'The Growing Importance of Cognitive Skills in Wage Determination', Review of Economics and Statistics, 77 (2), pp.251-266.

Taubman, P. and Wales, T. (1974), Higher Education and Earnings: College Education as an Investment and a Screening Device, Carnegie Commission on Higher Education and National Bureau of Economic Research General Series 101, McGraw-Hill: New York.

Willis, R. J., and Rosen, S. (1979), 'Education and Self-Selection', Journal of Political Economy, 79(5, 2), S7-S36. 


\section{CENTRE FOR ECONOMIC PERFORMANCE Recent Discussion Papers}

477 P. Willman

476 D. Marsden

S. French

K. Kubo

475 S. Gomulka

474 S. Burgess

H. Turon

473 D. Robertson

J. Symons

472 B. Bell

S. Nickell

G. Quintini

471 M. Dabrowski

S. Gomulka

J. Rostowski

470 B. Petrongolo

C. A. Pissarides

469 W. H. Buiter

468 A. S. Litwin

467 P. B. Kenen

466 S. Gomulka

J. Lane

465 F. Green

S. McIntosh

464 J. P. Neary

463 M. Güell
The Viability of Trade Union Organisation: A Bargaining Unit Analysis

Why Does Performance Pay De-Motivate? Financial Incentives versus Performance Appraisal

Macroeconomic Policies and Achievements in Transition Economies, 1989-1999

Unemployment Dynamics, Duration and Equilbirum:

Evidence from Britain

Factor Residuals in SUR Regressions: Estimating Panels Allowing for Cross Sectional Correlation

Wage Equations, Wage Curves and All That

Whence Reform? A Critique of the Stiglitz Perspective

Looking Into the Black Box: A Survey of the Matching Function

Monetary Misconceptions

Trade Unions and Industrial Injury in Great Britain

Currency Areas, Policy Domains and the Institutionalization of Fixed Exchange Rates

A Simple Model of the Transformational Recession Under a Limited Mobility Constraint

Working on the Chain Gang? An Examination of Rising Effort Levels in Europe in the 1990s

R\&D in Developing Countries: What Should Governments Do?

Employment Protection and Unemployment in an Efficiency Wage Model 
462 W. H. Buiter

461 M. Güiell

460 P. Ramezzana

458 R. Griffith

S. Redding

J. Van Reenen

$457 \quad$ J. Swaffield

456 C. Dougherty

455 S. Machin

454

453

H. Gospel

G. Lockwood

P. Willman

452 D. Metcalf

K. Hansen

A. Charlwood

451

P. Martin

H. Rey

450 P. Martin

H. Rey

449 A. Manning

$448 \quad$ S. Nickell

L. Nunziata

447 W. Buiter
Optimal Currency Areas: Why Does the Exchange Rate Regime Matter?

Fixed-Term Contracts and Unemployment: An Efficiency

Wage Analysis

Per Capita Income, Demand for Variety, and International Trade: Linder Reconsidered

Tenures that Shook the World: Worker Turnover in Russia, Poland and Britain

Mapping the Two Faces of R\&D: Productivity Growth in a Panel of OECD Industries

Gender, Motivation, Experience and Wages

Impact of Work Experience and Training in the Current and Previous Occupations on Earnings: Micro Evidence from the National Longitudinal Survey of Youth

Union Decline in Britain

Teachers Before the 'Threshold'

The Right to Know: Disclosure of Information for

Collective Bargaining and Joint Consultation

Unions and the Sword of Justice: Unions and Pay Systems, Pay Inequality, Pay Discrimination and Low Pay

Financial Integration and Asset Returns

Financial Super-Markets: Size Matters for Asset Trade

Labour Supply, Search and Taxes

Employment Patterns in OECD Countries

The Fallacy of the Fiscal Theory of the Price Level

To order a discussion paper, please contact the Publications Unit Tel 02079557673 Fax 02079557671 Email info@cep.lse.ac.uk Web site http://ceplse.ac.uk 